\title{
Cigarette smoke inhalation and lung damage in smoking volunteers
}

\author{
K.D. Clark*, N. Wardrobe-Wong*, J.J. Elliott+, P.T. Gill+, N.P. Tait+, P.D. Snashall*
}

Cigarette smoke inhalation and lung damage in smoking volunteers. K.D. Clark, N. Wardrobe-Wong, J.J. Elliott, P.T. Gill, N.P. Tait, P.D. Snashall. CERS Journals Ltd 1998.

ABSTRACT: Cigarette smoking is the dominant risk factor for chronic obstructive pulmonary disease (COPD) but only 10-15\% of smokers develop the condition. Risk does not relate closely to cumulative cigarette consumption, perhaps because smokers vary in the degree and depth of smoke inhalation. This study examined the role of smoke inhalation in the development of COPD.

Eighty current smokers and 20 lifetime nonsmoking volunteers (aged 35-65 yrs) were recruited. Lung function variables were measured and high-resolution computed tomography (HRCT) scans performed. Smoke inhalation was assessed by CO boost (the increment of expired carbon monoxide 5 min after smoking a cigarette) and serum cotinine.

Mean CO boost was 6.3 parts per million (ppm) in smokers with low $\mathrm{CO}$ transfer coefficients $(K C O)$ and $2.9 \mathrm{ppm}$ in those with normal $K \mathrm{CO}(\mathrm{p}=0.006) ; 7.2 \mathrm{ppm}$ in smokers with both HRCT-defined emphysema and a low KCO and $2.6 \mathrm{ppm}$ in those with neither abnormality $(p=0.002) ; 4.5 \mathrm{ppm}$ in smokers with HRCT-defined emphysema alone and $2.8 \mathrm{ppm}$ in those without $(\mathrm{p}=0.08)$. Mean serum cotinine was $328 \mathrm{ng} \cdot \mathrm{mL}^{-1}$ in smokers with chronic productive cough and $243 \mathrm{ng} \cdot \mathrm{ml} \mathrm{L}^{-1}$ in those without $(\mathrm{p}=0.005)$. Lifetime nonsmokers had normal HRCT scans, lung function and serum cotinine.

Emphysema is associated with high alveolar smoke exposure as measured by $\mathrm{CO}$ boost. Productive coughing is associated with high nicotine uptake, probably from airway smoke particle deposition.

Eur Respir J 1998; 12: 395-399.
School of Clinical Medical Sciences, University of Newcastle upon Tyne, Newcastle upon Tyne, UK. *Depts of Cardio-respiratory Medicine and +Radiology, North Tees General Hospital, Stockton on Tees, UK.

Correspondence: P.D. Snashall

Dept of Medicine

North Tees General Hospital

Stockton on Tees

Cleveland TS19 8PE

UK

Fax: 441642624919

Keywords: Airflow obstruction

cotinine

emphysema

lung function

productive cough

smoking

Received: June 31997

Accepted after revision April 71998

Funded by grants from the Northern \& Yorkshire Regional Health Authority and North Tees Health (NHS) Trust.
Cigarette smoking is the dominant risk factor for the development of chronic obstructive pulmonary disease (COPD) $[1,2]$, but only $10-15 \%$ of smokers develop the condition [1]. Several risk factors for COPD are known [2] but only apply to a small minority of cases. There is only a weak relationship between the lifetime number of cigarettes smoked and risk of COPD [2, 3]. Smoke must be inhaled to damage the lung and it is the cumulative dose of smoke inhaled that would seem to be relevant to the development of lung injury. Smokers differ in the number and size of puffs taken per cigarette, depth and duration of inhalation, cigarette yield and size of discarded butt $[4,5]$. This study, therefore, investigated whether risk is more closely determined by aspects of smoking behaviour that affect the depth, duration and quantity of smoke inhalation.

Indices of smoke inhalation were measured and related to productive cough, airflow obstruction and emphysema in smoking volunteers. These indices are boost of carbon monoxide $(\mathrm{CO})$ in alveolar air after smoking one cigarette [6] and serum levels of the major primary metabolite of nicotine, cotinine [7]. Since lung damage may affect smoking behaviour or absorption of tobacco products smokers with a previously established diagnosis of COPD were not studied.

\begin{abstract}
Methods
Eighty current cigarette smokers ( $\check{5} 5$ cigarettes $\cdot$ day $\left.^{-1}\right)$ aged 35-65 yrs (mean (SD) age 51 (7.7) yrs) (41 males and 39 females) and 20 lifetime nonsmoking controls (ð1 cigarette $\cdot$ day $^{-1}$ for $1 \mathrm{yr}$ ) aged 50 (8.1) yrs ( 7 males and $13 \mathrm{fe}$ males) were recruited after publicity in local media. All subjects were Caucasians. Exclusion criteria were a forced expiratory volume in one second $(\mathrm{FEV} 1)<1.5 \mathrm{~L}$, asthma, bronchodilator or corticosteroid medication and use of other tobacco products. All subjects who fulfilled the inclusion and exclusion criteria were included. The study was approved by the North Tees Local Research Ethics Committee and written consent obtained.

Cumulative lifetime smoking was quantified as pack-yrs and the brand of cigarette smoked was recorded. Subjects completed a Medical Research Council (MRC) Respiratory Health Questionnaire. Blood was taken for measurements of serum $\alpha_{1}$-protease inhibitor ( $\alpha_{1}$-antitrypsin) and haemoglobin concentrations.

High-resolution computed tomography (HRCT) scanning was performed using an IGE Sytec 3000i CT scanner. Three $1 \mathrm{~mm}$ cuts from the upper, middle and lower
\end{abstract}


zones of the right lung were taken at total lung capacity (TLC). Images were examined for areas of abnormally low radiographic density by two radiologists who worked independently and were unaware of the subjects' smoking status. Emphysema was graded using the criteria of REMY$\mathrm{J}_{\text {ARDIN }}$ et al. [8], i.e. grade 1: $<25 \%$ of lung fields affected by emphysema; grade $2:>25,<50 \%$; grade $3:>50,<75 \%$; and grade $4:>75 \%$.

\section{Lung function}

Forced spirometry, lung volumes (helium dilution and body plethysmography) and carbon monoxide transfer were measured using automated apparatus (model TTUSA, PK Morgan, Chatham, UK) and adjusted to body temperature and ambient pressure and saturated with water vapour. Forced expiratory manoeuvres were repeated until duplicate estimates of forced vital capacity (FVC) and FEV1 were within 5\% and lung volume measurements repeated until duplicate measurements of TLC were within 7\%. Carbon monoxide transfer was measured by the single-breath method [9] using a $9 \mathrm{~s}$ breath-hold time. Duplicate measurements were accepted where estimates of transfer factor $(T \mathrm{~L}, \mathrm{CO})$ and effective alveolar volume $(\mathrm{VA})$ were within $5 \%$. The $\mathrm{CO}$ transfer coefficient $(K \mathrm{CO})$ was derived $(=T \mathrm{~L}, \mathrm{CO} /$ $V A)$. Four subjects failed to achieve acceptable $T \mathrm{~L}, \mathrm{CO}$ reproducibility. Predicted lung function values used were from a nonsmoking, Caucasian, urban British population [10].

\section{Carbon monoxide boost with smoking}

$\mathrm{CO}$ in expired, end-tidal air (COET) was measured using an infra-red CO analyser (Micro Smokerlyzer, Bedfont, Upchurch, UK) immediately before and $5 \mathrm{~min}$ after smoking 1 cigarette of the subject's usual brand. CO boost is the increment of COET with smoking. The manoeuvre consists of a $15 \mathrm{~s}$ breath-hold at TLC followed by slow exhalation to residual volume (RV) into the analyser. Multiple measurements were made on separate days (four measurements in 11 subjects; three in 26; two in 28; one in 12). Most smokers had one or more measurement 08:3009:30 $\mathrm{h}$ prior to smoking that day; further measurements were made at other times without smoking abstinence. Three subjects failed to attend for $\mathrm{CO}$ boost measurements.

\section{Serum cotinine}

Blood was taken between 08:30 and 09:30 h. Subjects were asked not to smoke that day prior to blood sampling. Cotinine was measured by a rapid gas-liquid chromatographic method [11].

\section{Statistics}

Data were analysed using a statistical package (SPSS, Chicago, IL, USA). Means were compared using the t-test for independent samples. To allow comparison of means of different lung function measures means were represented as standardized residuals (SR) with their $95 \%$ confidence intervals. Correlation was by least squares regression using pair-wise missing value treatment. Multiple linear regression was used to explore the relationships among lung function, HRCT findings, cotinine and $\mathrm{CO}$ boost. A pvalue of $<0.05$ was accepted as significant and mean -1.645 SD was adopted as the lower limit of normal FEV1 and $K \mathrm{CO}$. Values below this will occur by chance on $5 \%$ of occasions in a normal, nonsmoking population [10].

\section{Results}

\section{$\alpha_{l}$-Protease inhibitor status and haemoglobin}

Plasma $\alpha_{1}$-protease inhibitor (PI) levels were normal in all subjects, suggesting a PI M genotype. Mean (SD) concentration was 2,199 (429) $\mu \mathrm{g} \cdot \mathrm{mL}^{-1}$. Levels were not significantly different in subjects with and without airflow obstruction, emphysema or productive cough. Haemoglobin concentrations were normal in all subjects.

\section{Smoking subjects}

Smoking and cigarette type. Pack-yrs varied from 8-89 (fig. 1). The tar yields of brands smoked are shown in figure 2. All but six subjects smoked filter cigarettes, five of whom smoked roll-up cigarettes.

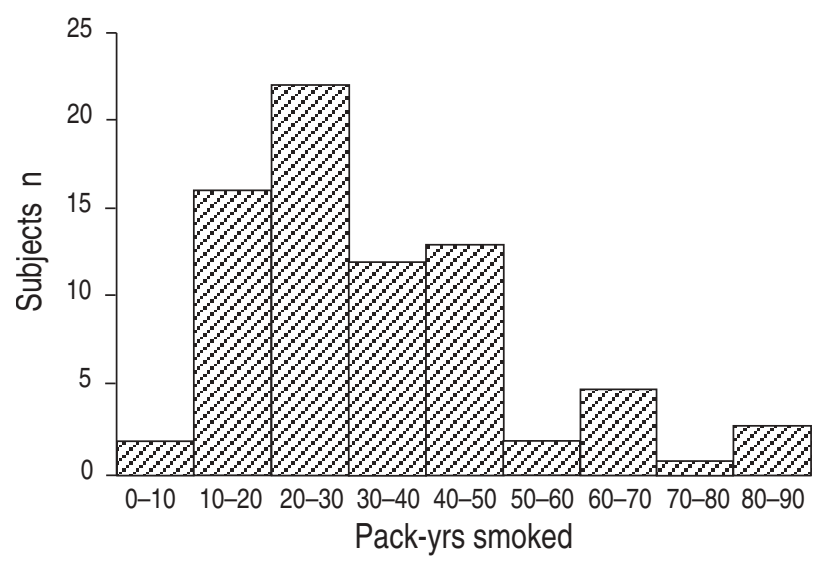

Fig. 1. - Smoking history of 80 volunteers.

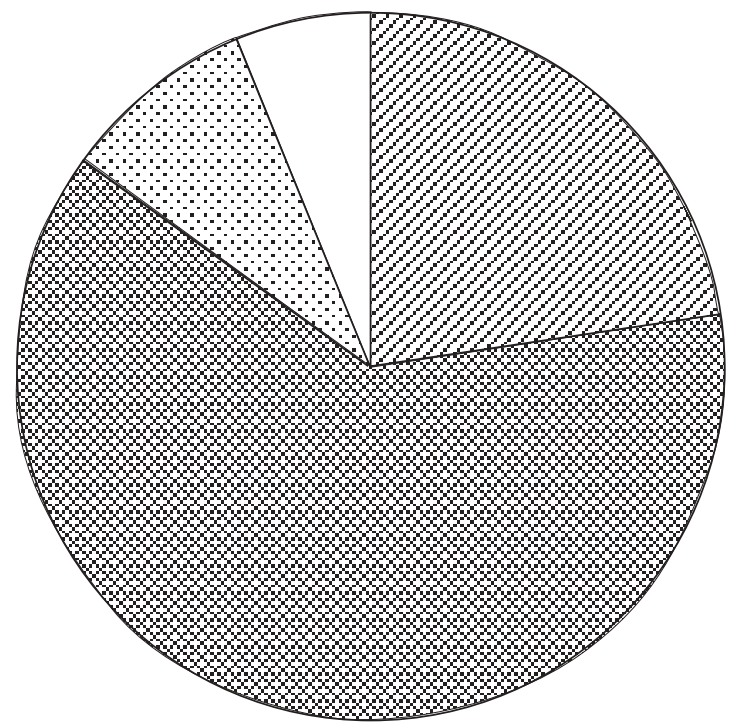

Fig. 2. - Breakdown of type and tar content of "usual brands" smoked by study volunteers. $\square$ : roll-up; $\mathbb{Z l}:<10 \mathrm{mg} ; \$: 10-12 \mathrm{mg}$; $>12 \mathrm{mg}$. 
Productive cough. Sixteen smokers had a productive cough for $>3$ months $\cdot \mathrm{yr}^{-1}$ for $>2 \mathrm{yrs}$.

Lung function. Mean FEV1 and KCO were significantly lower than in lifetime nonsmokers and mean FRC was higher (table 1). In smokers with productive cough, FEV1 was significantly reduced compared with those without cough (table 2). Ten smokers had reduced KCO. TLC, measured by helium dilution, in smokers was $5.96 \pm 1.23 \mathrm{~L}$ compared with $5.87 \pm 1.30 \mathrm{~L}$ in nonsmokers (NS); in subjects with emphysema, TLC averaged $5.70 \pm 0.99$ L compared with $5.93 \pm 1.36 \mathrm{~L}$ (Ns) in those without; in subjects with reduced $K C O$, mean TLC was $5.84 \pm 1.03 \mathrm{~L}$ compared with $5.88 \pm 1.34 \mathrm{~L}$ (Ns) in those with normal KCO. Lung volumes measured by body plethysmography did not differ significantly from those measured by helium dilution.

High-resolution computed tomography. In their first examination of the images the radiologists agreed on the presence of emphysema in 14 smokers and its absence in 55 smokers but they disagreed on 11 cases. To resolve these differences they viewed the images together and agreed that six had emphysema and five did not. Emphysema was graded as 1 in 18 smokers ( 17 focal), as 2 in one smoker and as 4 in one smoker. KCO was reduced in six of those with HRCT-defined emphysema.

CO boost. Presmoking COET was $8.4 \pm 7.7$ parts per million (ppm) (mean $\pm \mathrm{SD})$; and postsmoking COET $11.7 \pm 9.8 \mathrm{ppm}$, giving a mean $\mathrm{CO}$ boost of $3.3 \pm 3.6 \mathrm{ppm}$. There was no significant relationship between the presmoking level and the $\mathrm{CO}$ boost $(\mathrm{r}=-0.1, \mathrm{p}>0.05)$ and no difference in $\mathrm{CO}$ boost with or without prior smoking abstinence.

In 10 subjects with significantly low $\mathrm{KCO}$, the mean $\mathrm{CO}$ boost was $6.3 \mathrm{ppm}$, compared with $2.9 \mathrm{ppm}$ in those with normal KCO $(\mathrm{p}=0.006)$. In six smokers with HRCT-defined emphysema plus a significantly reduced $K \mathrm{CO}$, the mean boost was $7.2 \mathrm{ppm}$, compared with $2.6 \mathrm{ppm}$ in those with neither of these abnormalities $(p=0.002)$. In 20 subjects with HRCT-defined emphysema, the CO boost was $4.5 \mathrm{ppm}$, compared with $2.8 \mathrm{ppm}$ in subjects with normal HRCT scans $(p=0.08)$. The CO boost was not significantly raised in smokers with low FEV1 or chronic productive cough.

Serum cotinine. Cotinine was $37 \%$ higher in smokers with productive cough than in those without $(p<0.005)$. These subjects did not otherwise differ significantly in the nicotine or tar contents of their cigarettes, daily nicotine exposure (nicotine content $\times$ number smoked) or pack yrs, but the calculated daily tar exposure averaged $36 \%$ higher $(\mathrm{p}=$ 0.079 ). There were no significant differences in cotinine between those with and without airflow obstruction or em-physema. The mean (SD) cotinine level in female smokers was 219.5 (109.4) ng. $\mathrm{mL}^{-1}$, compared with 299.7 (119.3) $\mathrm{ng} \cdot \mathrm{mL}^{-1}$ in male smokers $(\mathrm{p}=0.004)$, although there were no sex differences in daily nicotine exposure or $\mathrm{CO}$ boost.

\section{Correlations}

Correlations between lung function and measures of smoker inhalation are shown in table 3 . In smokers the correlation between $\mathrm{FEV}_{1} \%$ predicted and pack-yrs $(\mathrm{r}=$ $-0.22, \mathrm{p}=0.056)$ fell just short of statistical significance. $K \mathrm{CO}(\%$ pred $)$ correlated with cotinine $(\mathrm{r}=-0.28, \mathrm{p}=0.016)$

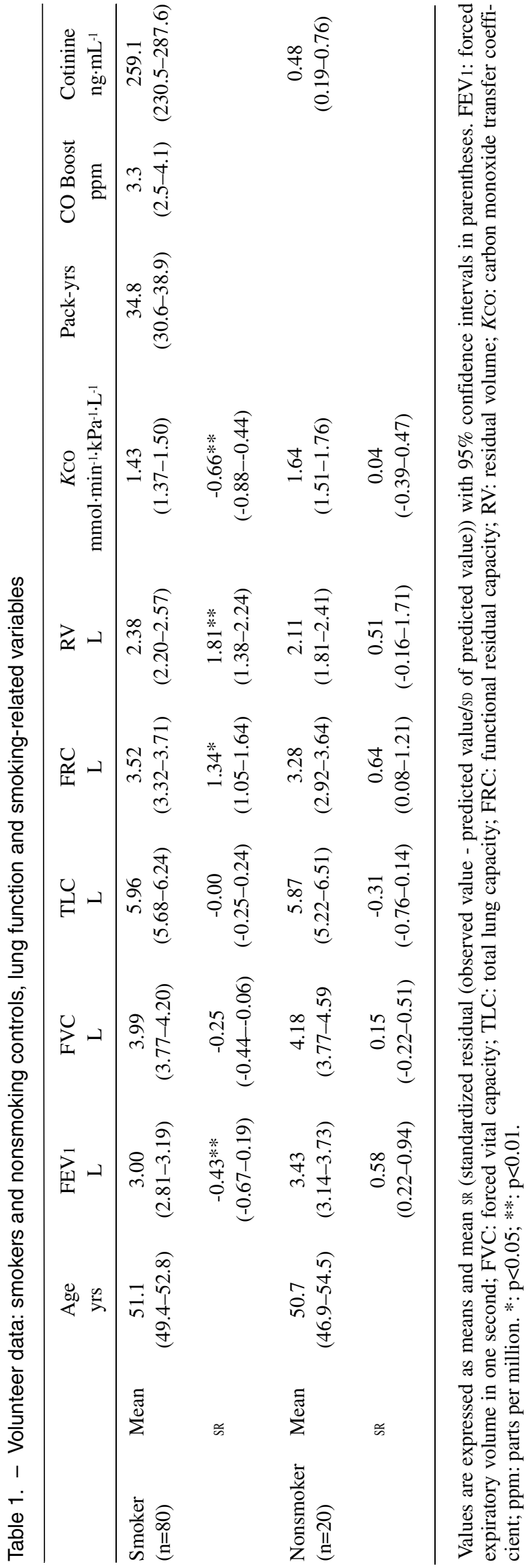


Table 2. - Smoking volunteer data: symptoms, lung function and high-resolution computed tomography (HRCT) findings

\begin{tabular}{|c|c|c|c|c|c|c|c|c|}
\hline & $\mathrm{n}$ & $\begin{array}{l}\text { Age } \\
\text { yrs }\end{array}$ & $\begin{array}{c}\text { FEV } 1 \\
\text { SR }\end{array}$ & $\begin{array}{l}\mathrm{RV} \\
\text { SR }\end{array}$ & $\begin{array}{c}\text { KCO } \\
\text { SR }\end{array}$ & Pack-yrs & $\begin{array}{c}\text { CO boost } \\
\text { ppm }\end{array}$ & $\begin{array}{l}\text { Cotinine } \\
\mathrm{ng} \cdot \mathrm{mL}^{-1}\end{array}$ \\
\hline Productive cough & 16 & $\begin{array}{c}51.7 \\
(49.1-52.9)\end{array}$ & $\begin{array}{c}-1.01 \\
(-1.82--0.19)\end{array}$ & $\begin{array}{c}2.14 \\
(0.74-3.53)\end{array}$ & $\begin{array}{c}-0.63 \\
(-1.24--0.02)\end{array}$ & $\begin{array}{c}39.43 \\
(29.3-49.47)\end{array}$ & $\begin{array}{c}3.3 \\
(1.8-4.8)\end{array}$ & $\begin{array}{c}328.4 * * \\
(278.8-377.9)\end{array}$ \\
\hline No productive cough & 64 & $\begin{array}{c}51.0 \\
(47.2-56.2)\end{array}$ & $\begin{array}{c}-0.29 \\
(-0.52--0.07)\end{array}$ & $\begin{array}{c}1.74 \\
1.29-2.20\end{array}$ & $\begin{array}{c}-0.67 \\
(-0.91-0.42)\end{array}$ & $\begin{array}{c}33.71 \\
(29.10-38.32)\end{array}$ & $\begin{array}{c}3.3 \\
(2.3-4.2)\end{array}$ & $\begin{array}{c}243.5 \\
(211.2-275.8)\end{array}$ \\
\hline HRCT emphysema & 20 & $\begin{array}{c}54.8^{*} \\
(51.3-58.2)\end{array}$ & $\begin{array}{c}-0.19 \\
(-0.56-0.17)\end{array}$ & $\begin{array}{c}1.66 \\
0.95-2.37\end{array}$ & $\begin{array}{c}-1.29 * * \\
(-1.72-0.86)\end{array}$ & $\begin{array}{c}32.05 \\
(24.21-39.90)\end{array}$ & $\begin{array}{c}4.5 \\
(2.4-6.5)\end{array}$ & $\begin{array}{l}.5 \\
-335.1)\end{array}$ \\
\hline No HRCT emphysema & 60 & $\begin{array}{c}49.9 \\
(48.0-51.8)\end{array}$ & $\begin{array}{c}-0.51 \\
(-0.81--0.22)\end{array}$ & $\begin{array}{c}1.87 \\
1.33-2.41\end{array}$ & $\begin{array}{c}0.45 \\
(-0.69--0.21)\end{array}$ & $\begin{array}{c}35.67 \\
(30.72-40.61)\end{array}$ & $\begin{array}{c}2.8 \\
(2.0-3.6)\end{array}$ & $\begin{array}{c}246.9 \\
(211.0-282.7)\end{array}$ \\
\hline FEV1 $<$ pred-(1.645 sD) & 13 & $\begin{array}{c}51.6 \\
(46.5-56.7)\end{array}$ & - & $\begin{array}{c}3.24 * \\
2.11-4.38\end{array}$ & $\begin{array}{c}-0.73 \\
(-1.57-0.11)\end{array}$ & $\begin{array}{c}42.73 \\
(27.63-57.83)\end{array}$ & $\begin{array}{c}2.8 \\
(0.2-5.4)\end{array}$ & $\begin{array}{c}281.2 \\
(225.2-337.2)\end{array}$ \\
\hline FEV1 normal & 67 & $\begin{array}{c}51.0 \\
(49.2-52.9)\end{array}$ & - & $\begin{array}{c}1.57 \\
1.12-2.02\end{array}$ & $\begin{array}{c}-0.64 \\
(-0.86--0.42)\end{array}$ & $\begin{array}{c}33.42 \\
(29.20-37.63)\end{array}$ & $\begin{array}{c}3.3 \\
(2.5-4.2)\end{array}$ & $\begin{array}{c}255.4 \\
(223.1-287.7)\end{array}$ \\
\hline KCO <pred-(1.645 SD) & 10 & $\begin{array}{c}44.6 * * \\
(39.8-49.4)\end{array}$ & $\begin{array}{c}-0.23 \\
(-1.12-0.67)\end{array}$ & $\begin{array}{c}1.73 \\
1.01-2.44\end{array}$ & - & $\begin{array}{c}31.50 \\
(23.30-39.70)\end{array}$ & $\begin{array}{c}6.3 * * \\
(2.9-9.7)\end{array}$ & $\begin{array}{c}298.9 \\
(224.1-373.6)\end{array}$ \\
\hline KCO normal & 66 & $\begin{array}{c}51.8 \\
(50.0-53.6)\end{array}$ & $\begin{array}{c}-0.48 \\
(-0.74--0.21)\end{array}$ & $\begin{array}{c}1.89 \\
1.39-2.39\end{array}$ & - & $\begin{array}{c}34.42 \\
(29.74-39.10)\end{array}$ & $\begin{array}{c}2.9 \\
(2.1-3.7)\end{array}$ & $\begin{array}{c}250.4 \\
(218.4-282.4)\end{array}$ \\
\hline
\end{tabular}

Values are expressed as means and mean SR (standardized residual = (observed value - predicted value/sD or predicted value)) with 95\% confidence intervals in parentheses. FEV1: forced expiratory volume in one second; RV: residual volume; KCO: carbon monoxide transfer coefficient; ppm: parts per million. *: $\mathrm{p}<0.05 ; * *$ : $<<0.01$.

Table 3. - Correlations between lung function and measures of smoke inhalation

\begin{tabular}{|c|c|c|c|c|c|}
\hline & $\begin{array}{c}\mathrm{CO} \\
\text { boost }\end{array}$ & $\begin{array}{c}\text { Pack- } \\
\text { yrs }\end{array}$ & $\begin{array}{c}\text { Pack-yrs } \\
\times \text { CO } \\
\text { boost }\end{array}$ & Cotinine & $\begin{array}{c}\text { Cotinine } \\
\times \text { yrs } \\
\text { smoked }\end{array}$ \\
\hline FEV $1 \%$ pred & $\begin{array}{r}0.062 \\
(0.59)\end{array}$ & $\begin{array}{l}-0.218 \\
(0.056)\end{array}$ & $\begin{array}{l}-0.034 \\
(0.77)\end{array}$ & $\begin{array}{l}-0.031 \\
(0.79)\end{array}$ & $\begin{array}{l}-0.085 \\
(0.46)\end{array}$ \\
\hline КСO \% pred & $\begin{array}{l}-0.14 \\
(0.23)\end{array}$ & $\begin{array}{c}0.097 \\
(0.41)\end{array}$ & $\begin{array}{l}-0.063 \\
(0.60)\end{array}$ & $\begin{array}{l}-0.275 \\
(0.016)\end{array}$ & $\begin{array}{l}-0.25 \\
(0.03)\end{array}$ \\
\hline
\end{tabular}

Significance levels are shown in parentheses. FEV1: forced expiratory volume in one second; $K \mathrm{CO}$ : carbon monoxide transfer coefficient.

and (cotinine $\times$ yrs smoked $)(r=-0.25, p=0.03)$. Serum cotinine correlated with cigarette nicotine yield $(\mathrm{r}=0.39, \mathrm{p}=$ $0.0009)$ and the product of yield and cigarettes day $^{-1}(\mathrm{r}=0.35$, $\mathrm{p}=0.003)$. Using multiple regression, correlating FEV1 or $K \mathrm{CO}$ with $\mathrm{CO}$ boost, pack-yrs, cotinine and cigarette yield of $\mathrm{CO}$ and nicotine, the multiple r-value for $\mathrm{FEV} 1=0.29$ and for $\mathrm{KCO}=0.4$. KCO correlated significantly with cotinine $(\mathrm{p}=0.012)$ and FEV1 with pack yrs $(\mathrm{p}=0.01)$.

\section{Lifetime nonsmoking subjects}

Mean lung function values were close to predicted [10] (table 1). No HRCT-defined emphysema was detected. No cotinine was detected in 10 volunteers. The highest level was $1.86 \mathrm{ng} \cdot \mathrm{mL}^{-1}$, possibly derived from passive smoking or diet $[12,13]$.

\section{Discussion}

This study found that CO boost, an index of smoke inhalation, was significantly higher in subjects with emphysema demonstrated by either a low KCO or a combination of low KCO and HRCT changes. Similarly, serum cotinine, an index of nicotine absorption over the previous 24-48 h, was elevated in subjects with chronic productive cough. These findings suggest that patterns of increased smoke inhalation are either risk factors for the development of these features of COPD or a consequence of their development.
The increases in COET after smoking demonstrates that smoke has been inhaled into the alveoli [14-16] and is a function of puff volume and inhalation duration [17]. $\mathrm{CO}$ boost, therefore, conveys information about aspects of smoking behaviour which are known to be highly variable between smokers [5, 18]. For instance, in asymptomatic smokers inhalation volumes varied seven-fold and inhalation times three-fold [5]. Inhalation patterns affect the dose, distribution and concentration of smoke in the lung and, therefore, are likely to be relevant to the development of lung damage.

For COET to increase, $\mathrm{CO}$ in smoke has to transfer across the alveolar capillary membrane. Where KCO is reduced, one would predict that $\mathrm{CO}$ boost would be proportionally reduced, but in fact the opposite is true. Subjects with the lowest capacity to transfer $\mathrm{CO}$ have the highest $\mathrm{CO}$ boosts and, hence, at a purely mechanical level, increased $\mathrm{CO}$ boosts cannot be a consequence of emphysema. It remains possible that smoking behaviour is changed by emphysema, although the reason for this is unclear. Nicotine dependence is known to influence smoking behaviour [19], but nicotine absorption is affected little by the depth and duration of inhalation, factors important to the absorption of $\mathrm{CO}[16,17]$.

Smoking may cause a transient defect in CO transfer, altering the relationship between carboxyhaemoglobin $(\mathrm{COHb})$ and COET [20]. This may explain the negative COET increments on smoking that we and others have recorded. Similar mechanisms may, conceivably, underlie the loss of KCO demonstrated in middle-aged male smokers [21], which is reversible on quitting. We and others $[20,22]$ have also demonstrated consistent intersubject differences in $\mathrm{CO}$ boost, but these have not previously been related to lung disease.

Nicotine, which is carried with tar in the particulate phase of smoke, will tend to deposit preferentially in airways, and being highly lipid-soluble, will be absorbed through airway epithelia. Nicotine absorption is influenced by smoking behaviour and nicotine yield [16]. Increased airway particle deposition, particularly of tar, may explain the finding of an association between chronic productive 
cough and high serum cotinine. Hypersecretion of mucus is positively related to the tar content of cigarettes and the cigarettes.day-1 [23] and a positive trend was shown between productive cough and the product of cigarette tar content and cigarettes $\cdot$ day $^{-1}$. Serum cotinine was higher in males than females, perhaps owing to the higher smoke particle retention in males [24] or slower metabolism of nicotine to cotinine in females [25].

HRCT scanning demonstrated emphysema in 20 (25\%) of smokers, a prevalence in line with another HRCT study of smokers [8]. Of those with radiographically defined emphysema, only six had a reduction in KCO and in 14 subjects $K \mathrm{CO}$ was in the normal range. The normal range of $K \mathrm{CO}$ is very wide, and some subjects may have suffered considerable reductions in $\mathrm{KCO}$ while still in the normal range but, equally, it seems that HRCT scanning frequently demonstrates focal emphysema before any general damage to the gas-exchanging lung parenchyma has occurred. Ten smokers had reduced $K \mathrm{CO}$, unaccompanied by any increase in lung volumes, measured by helium dilution and body plethysmography, and most likely due to mild emphysema [26]. For ethical reasons, scanning was limited to three cuts from the right lung and, consequently, significant areas of focal damage in some smokers with low KCO may have been missed.

Smokers with emphysema inhale in such a way as to achieve high $\mathrm{CO}$ boosts but normal plasma cotinine; smokers with cough have high cotinine levels but normal CO boosts. These differential effects are probably achieved by intersubject differences in volume, depth and duration of inhalation which will influence $\mathrm{CO}$ uptake much more than nicotine uptake $[16,17]$. Conversely, varying the number and size of puffs taken from a cigarette should affect $\mathrm{CO}$ boost and cotinine in parallel. No relationships were seen between smoke inhalation and airflow obstruction. Logically, the development of airflow obstruction may relate to the concentration of smoke in small airways and centrilobular alveoli but this distribution would not necessarily cause high CO boost or cotinine. Direct observation of smoking behaviour is required to confirm these mechanisms.

\section{References}

1. Hanrahan JP, Sherman CB, Bresnitz EA, Emmons KM. Cigarette smoking and health. Am J Respir Crit Care Med 1996; 153: 861-865.

2. Higgins M. Risk factors associated with chronic obstructive lung disease. Ann NY Acad Sci 1991; 624: 7-17.

3. Dockery DW, Speizer FE, Ferris BG Jr. Cumulative and reversible effects of lifetime smoking on simple tests of lung function in adults. Am Rev Respir Dis 1988; 137: 286-292.

4. Rawbone RG, Murphy K, Tate ME, Kane SJ. The analysis of smoking parameters, inhalation and absorption of tobacco smoke in studies of human smoking behaviour. In: Thornton RE, ed. Smoking Behaviour: Physiological and Pyschological Influences, Edinburgh, Churchill Livingstone 1978; p. 171-194.

5. Tobin M, Jenouri G, Sackner M. Subjective and objective measurements of cigarette smoke inhalation. Chest 1982; 82: 696-700.

6. Rawbone RG, Coppin CA, Guz A. Carbon monoxide in alveolar air as an index of exposure to cigarette smoke. Clin Sci Mol Med 1976; 51: 495-501.

7. Muranaka H, Higashi E, Itani S, Shimizu Y. Evaluation of nicotine, cotinine, thiocyanate, carboxyhemoglobin, and expired carbon monoxide as biochemical tobacco smoke uptake parameters. Int Arch Occup Environ Health 1988; 60: $37-41$.

8. Remy-Jardin M, Remy J, Boulenguez C, Sobaszek A. Morphologic effects of cigarette smoking on airways and pulmonary parenchyma in healthy adult volunteers: CT evaluation and correlation with pulmonary function tests. Radiology 1993; 186: 107-115.

9. Ogilvie CM, Forster RE, Blakemore WS. A standardized breath holding technique for the clinical measurement of the diffusing capacity of the lung for carbon monoxide. $J$ Clin Invest 1957; 36: 1-17.

10. Roberts CM, MacRae KD, Winning AJ, Adams L. Reference values and prediction equations for normal lung function in a non-smoking white urban population. Tho$\operatorname{rax} 1991$; 46: 643-650.

11. Feyerabend C, Russell MAH. A rapid gas-liquid chromatographic method for the determination of cotinine and nicotine in biological fluids. J Pharm Pharmacol 1990; 42: 450-452.

12. Idle JR. Titrating exposure to tobacco smoke using cotinine - a minefield of misunderstanding. $J$ Clin Epidemiol 1990; 43: 313-317.

13. Tunstall-Pedoe H, Woodward M, Brown CA. Tea drinking, passive smoking, smoking deception and serum cotinine in the Scottish Heart Health Study. J Clin Epidemiol 1991; 44: 1411-1414.

14. Adams L, Lee C, Rawbone R, Guz A. Patterns of smoking: measurement and variability in asymptomatic smokers. Clin Sci 1983; 65: 383-392.

15. Kirkham AJT, Guyett AR, Cumming G. Acute effect of smoking on rebreathing carbon monoxide and alveolar oxygen. Clin Sci 1988; 75: 371-373.

16. Herning RI, Jones RT, Benowitz NL, Mines AH. How a cigarette is smoked determines blood nicotine levels. Clin Pharmacol Ther 1983; 33: 84-90.

17. Zacny JP, Stitzer ML, Brown FJ, Jingling JE. Human cigarette smoking: effects of puff and inhalation parameters on smoke exposure. J Pharmacol Exp Ther 1986; 240: 554-564.

18. Medici T, Unger S, Ruegger M. Smoking pattern of smokers with and without tobacco-smoke-related lung diseases. Am Rev Respir Dis 1985; 131: 385-388.

19. Ashton C, Golding J. In: Ney T, Gale A, eds. Smoking: Motivation and Models. London, Wiley, 1989; p. 21.

20. McBride MJ, Guyett AR, Kirkham AJT, Cumming G. Assessment of smoking behaviour and ventilation with cigarettes of differing nicotine yields. Clin Sci 1984; 67: 619-631.

21. Watson A, Joyce H, Hopper L, Pride NB. Influence of smoking habits on change in carbon monoxide transfer factor over 10 years in middle aged men. Thorax 1993; 48: 119-124.

22. Guyatt AR, Kirkham AJT, Mariner DC, Cumming G. Is alveolar carbon monoxide an unreliable index of carboxyhaemoglobin changes during smoking in man? Clin Sci 1988; 74: 29-36.

23. Higenbottam T, Clark T, Shipley M, Rose G. Lung function and symptoms of cigarette smokers related to tar yield and number of cigarettes smoked. Lancet 1980; i: 409-412.

24. The Health Consequences of Smoking: Chronic Obstructive Lung Disease. A report of the Surgeon General US. Rockville, MD, Dept of Health and Human Services, Office on Smoking and Health, 1984.

25. Benowitz NL, Jacob PI. Daily intake of nicotine during cigarette smoking. Clin Pharmacol Ther 1984; 35: 499504

26. Gould GA, Redpath AT, Ryan M, Warren PM. Lung CT density correlates with measurements of airflow limitation and the diffusing capacity. Eur Respir J 1991; 4: 141146. 